\title{
CHANGES OF ULTRASTRUCTURE AND CYTOPLASMIC FREE CALCIUM IN GLADIOLUS X HYBRIDUS VAN HOUTTE ROOTS INFECTED BY ASTER YELLOWS PHYTOPLASMA
}

\author{
ANNA RUDZIŃSKA-LANGWALD ${ }^{1}$, MARIA KAMIŃSKA ${ }^{2}$ \\ ${ }^{1}$ Department of Botany, Faculty of Agriculture, Warsaw Agriculture University \\ Rakowiecka 26/30, 02-528 Warsaw, Poland \\ e-mail: rudzinska@delta.sggw.waw.pl \\ ${ }^{2}$ Research Institute of Pomology and Floriclture \\ Pomologiczna 18, 96-100 Skierniewice, Poland
}

(Received: November 20, 2002. Accepted: August 18, 2003)

\begin{abstract}
Roots of Gladiolus $x$ hybridus Van Houtte plants infected with aster yellows phytoplasma were examined. The infected plants had a reduced root system in comparison to control plants. Their roots were thinner and the stele organisation was changed. Phytoplasmas were present in sieve tubes, companion cells and phloem parenchyma cells of the infected plant roots. Free calcium ions were localized in the cells of infected plants. Cells of the stele of infected roots, especially these infected with phytoplasmas, showed an increase of calcium antimonite deposits in theirs protoplasts. Also the number of calcium antimonite deposits increased in sieve tubes of infected roots. The deposits were present on plasma membrane, around the sieve tube plate and also in the lumen of the sieve tube. The increase of free calcium ions in sieve tubes did not cause the occlusion of sieve tube pores. Companion cells and some parenchyma cells with phytoplasmas did not react to phytoplasma infection with an increase of $\mathrm{Ca}^{2+}$ ions in protoplast. The parenchyma cells showing signs of degeneration reacted with high increase of calcium ions. The $\mathrm{Ca}^{2+}$ ions were present mainly in cytoplasm of infected parenchyma cells. There were calcium antimonite deposits in infected plant roots xylem elements and in intracellular spaces of cortex parenchyma. Such deposits were not present in control plants.
\end{abstract}

KEY WORDS: phloem structure, calcium deposits, phytoplasma, aster yellows.

\section{INTRODUCTION}

Phytoplasmas (previously called mycoplasmalike organisms or MLOs) are divided into 20 groups, among which the aster yellows (AY) group is one of the biggest (Seemuller et al. 1998). AY phytoplasmas have been found in many herbaceous as well as in some woody plants producing typical symptoms like witches'-broom, flower distortion and virescence. Detection and identification of phytoplasmas have been largely based on their molecular characteristics revealed by the polymerase chain reactions (PCR) technique (Ahrens and Seemuller 1992). AY disease of gladiolus has been widely distributed throughout the USA, were it was first described in 1952 (Magie et al. 1952). The disease caused by phytoplasma was found in commercially produced Gladiolus plants by Kamińska et al. (1999).

Investigations of the last two decades have clearly established that $\mathrm{Ca}^{2+}$ acts as an intracellular messenger in coupling a wide range of extracellular signals to specific responses (Reddy 2001). Cytoplasmic free $\mathrm{Ca}^{2+}$ serves as a second messenger in many plant processes, among others in stress adaptation to pathogens' invasion (Blume et al. 2000; Rudd and Franklin-Tong 1999). Also several processes important for plant functioning, such like phloem and xylem transport, have been proposed to be regulated by changes in free $\mathrm{Ca}^{2+}$ (Brauer et al. 1998; Dematry et al. 1984) Knoblauch et al. (2001) showed that crystalloid p-protein disperses and occludes sieve plate pores after injury. This process was controlled by calcium fluxes. Also in phloem, $\mathrm{Ca}^{2+}$ has been proposed to participate in regulation of enzymes (Avdiushko et al. 1997).

The ultrastructural changes in roots of Gladiolus $x$ hybridus plants infected with phytoplasma were the subject of the present investigation, with special attention paid to changes in cytoplasmic free $\mathrm{Ca}^{2+}$ under stress of phytoplasma infection.

\section{MATERIAL AND METHODS}

Material

Plants of Gladiolus $x$ hybridus Van Houtte infected with AY phytoplasma were examined. Shooting corms of plants 
infected with AY phytoplasma prematurely developed multiple sprouts, which were weak and pale in color. Root formation was strongly inhibited. The control plants looked uninfected and PCR analysis failed to detect phytoplasma presence.

\section{Electronomicroscopical preparation}

Root tissues were examined with yhe aid of transmition electron microscopy (JEM 1220 electron microscope (Jeol, Japan)). Specimens were fixed for $4 \mathrm{~h}$ in a $3 \%$ glutaraldehyde supplemented with $4 \%$ paraformaldehyde in cacodylate buffer $\mathrm{pH}=7.2$. Postfixation in $1 \%$ osmium tetroxide for $2 \mathrm{~h}$ at $4^{\circ} \mathrm{C}$ was applied. The material was dehydrated in concentration gradients of ethanol (10-70\%), acetone (70$-100 \%)$ and embedded in Epon. The ultrathin sections on copper grids were stained with uranyl acetate and lead citrate in accordance to Sato (1967).

\section{Localisation of calcium}

Subcellular calcium localization was analyzed according to the method of Slocum and Roux (1982), with minor modifications (Jian et al. 1997). Specimens were fixed in a mixture of $2.5 \%(\mathrm{v} / \mathrm{v})$ glutaraldehyde, supplemented with $2 \%$ potassium antymonate in $0.1 \mathrm{M} \mathrm{K}$-phosphate buffer $\mathrm{pH}$ $=7.6$, for $12 \mathrm{~h}$ in temp. $4^{\circ} \mathrm{C}$. Postfixation in $1 \%$ osmium tetroxide with $2 \%$ potassium antymonate in $0.1 \mathrm{M} \mathrm{K}$-phosphate buffer $(\mathrm{pH}=7.6)$ for $2 \mathrm{~h}$ at $4^{\circ} \mathrm{C}$ was applied. For control, fragments of the roots were fixed and postfixed in the same mixtures, but without potassium antimonate. The material was dehydrated in concentration gradients of ethanol (10-70\%), acetone (70-100\%) and embedded in Epon resin. The ultrathin sections on copper grids were stained with uranyl acetate and lead citrate.

In order to confirm that the deposits contain $\mathrm{Ca}^{2+}$, chelating of $\mathrm{Ca}^{2+}$ with ethylene glycol-bis $\mathrm{N}, \mathrm{N}, \mathrm{N}^{\prime}, \mathrm{N}^{\prime}$ - tetraacetic acid (EGTA) was performed. The ultrathin sections on copper grids were immersed in $100 \mathrm{mM}$ EGTA ( $\mathrm{pH}$ 8.0 ), incubated for $1 \mathrm{~h}$ at $60^{\circ} \mathrm{C}$, and stained with uranyl acetate and lead citrate.

\section{RESULTS}

\section{Structural changes in infected Gladiolus roots}

Two kinds of roots of Gladiolus control plants, of which the roots grew directly from the corm and the lateral ones were examined. The thick contradicle roots were not examined. The main difference between roots growing directly from the corms and lateral was in xylem structure. The main roots had sclerenchyma cells with thick walls and no intercellular spaces situated in the center of the stele. The lateral roots had parenchyma cells with thin cell walls and big intercellular spaces situated in the same location (Fig. $1 \mathrm{~A}$ and $\mathrm{B})$. All the roots of infected plants grew directly from the corm and neither lateral nor contradicle roots were formed. In comparision to roots of uninfected plants the infected plant roots were thinner and shorter (Fig. 1C-F). The roots exhibited a week geotropism and they grew horizontally. The thinner the roots, the more disorganized was their stele structure. Although poliarch roots of control plants had a varying number of phloem bundles, the roots of infected plants had generally less phloem bundles than the control ones. There was also a reduction of vessels dia- meter in roots of infected plants. The structure of thicker roots from infected plants resembled that of the lateral roots from control plants, both because of the presence of parenchyma cells in the middle of stele and because of the similar vessels diameter (Fig. B, C). The thinnest roots had also a disorganized radial arrangement of xylem and phloem tissue (Fig. 1 E, F).

The phloem of uninfected plant roots was composed of approximately 10 cells. Among them there were parenchyma cells situated close to xylem, and also on the pericycle side. All of these parenchyma cells were strongly vacuolated, and had a thin layer of cytoplasm. In the middle of the phloem there were sieve tubes and few companion cells. The infected root phloem had a much less regular arrangement. The parenchyma cells situated close to the pericycle were filled with dark, homogenous masses (Fig. 25). Some of these cells had collapsed cell walls (Figs 24, 25, 27).

Endodermis of uninfected plants had thick radial cell walls. In roots of infected plants only few examples of such endodermis structure were found (Fig. 27). Most of the cells had no thickened walls and some of them were necrotised.

\section{Cytological changes in phytoplasma infected cells}

The phytoplasmas were present in sieve tubes (Figs 2-6), companion cells (Fig. 12) and phloem parenchyma cells (Figs 7 and 11-14) of infected Gladiolus roots. Most of the sieve tubes had phytoplasma in their protoplast, although the number of phytoplasmas observed on cross section of a single sieve tube was variable. Some of the sieve tubes had only few phytoplasma (Figs 4, 5) while the others had a lot of them. No signs of ultrastructural changes in most sieve tubes were observed.

Also some of the companion cells were infected with phytoplasma (Fig. 12). Regions filled with tightly packed phytoplasma cells were adjacent to homogenous regions of cytoplasm, where no membrane structures, ribosomes or phytoplasmas could be detected. The reduction of vacuoles and endoplasmatic reticulum cistern number was observed. Mitochondria were located near the nucleus or the cell wall, but not among the phytoplasma cells.

A number of phloem parenchyma cells were infected with phytoplasma. They showed various levels of degeneration (Figs 11-14), which were not correlated with a number of phytoplasma observed in the protoplast. The vacuoles of these cells were reduced and the cytoplasm compartment including phytoplasmas was enlarged. Paracrystals were present in vacuoles (Figs 24, 25). Also cells with dark homogenous protoplast, being in different stadium of necrotisation, were observed (Figs 24, 25).

Damages of infected cell walls occurred (Figs 7-9). In cell walls, around some of these damages, dark granular deposits of tannins appeared. They were observed in samples fixed by standart fixative.

\section{Phytoplasmas structure}

Phytoplasmas present in different cells of Gladiolus roots showed a strong pleomorphism. Some of them were of oval shape and had a well distinguished middle part, in which nucleoid could be observed (Figs 2, 3). Some of these phytoplasma cells had an elongated shape in cross sections. These particular phytoplasma cells occurred in sieve tubes (Fig. 2) and parenchyma cells (Fig. 12), with 


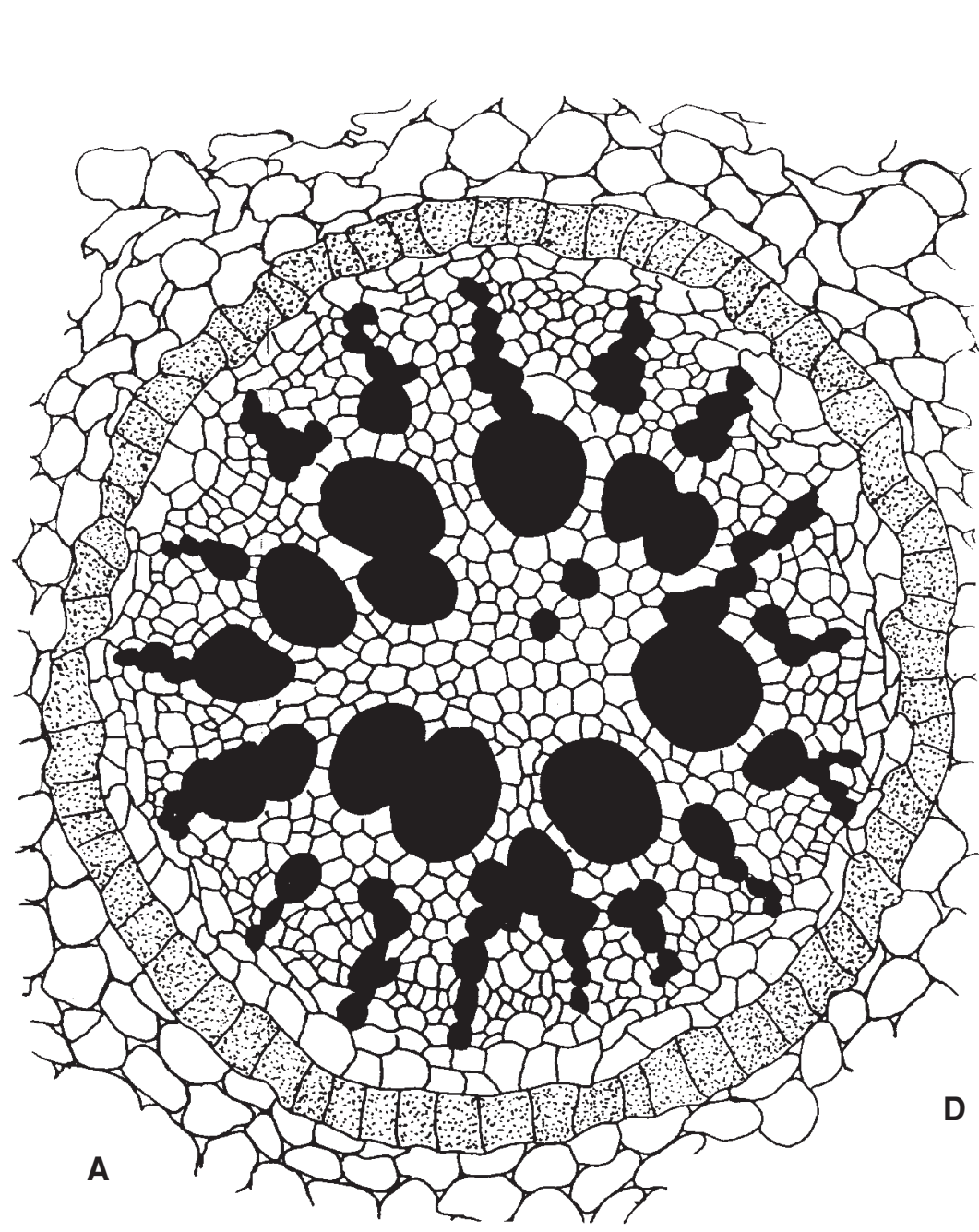

C
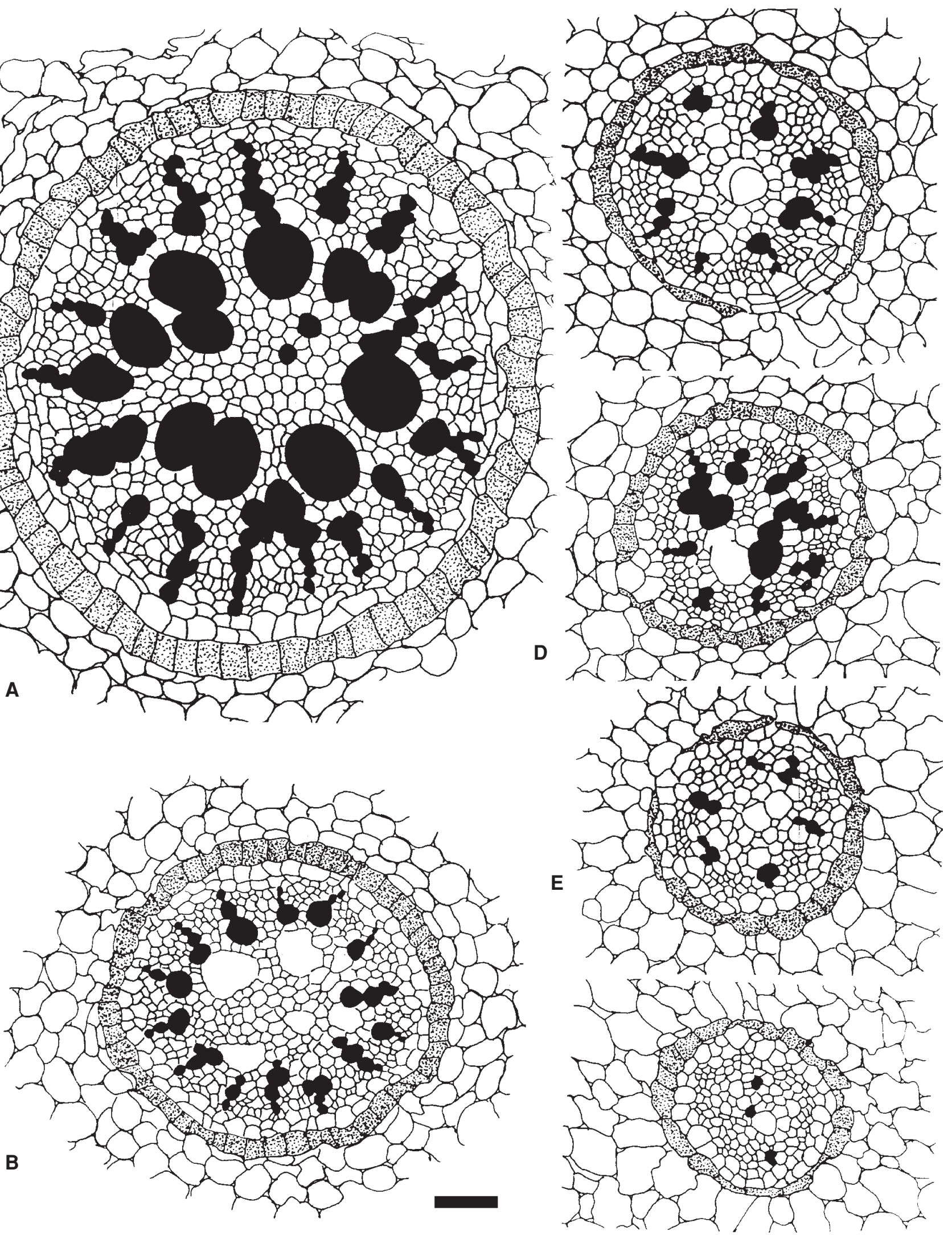

$\mathbf{F}$

Fig. 1. Schematic drawings based on photographs of cross sections of the Gladiolus root stele. A - main root from a control plant, B - lateral root from a control plant, C, D, E, F - roots from phytoplasma infected plants. The vessel lumens are stained black, endodermis is dotted. Bar $=50$ um. 

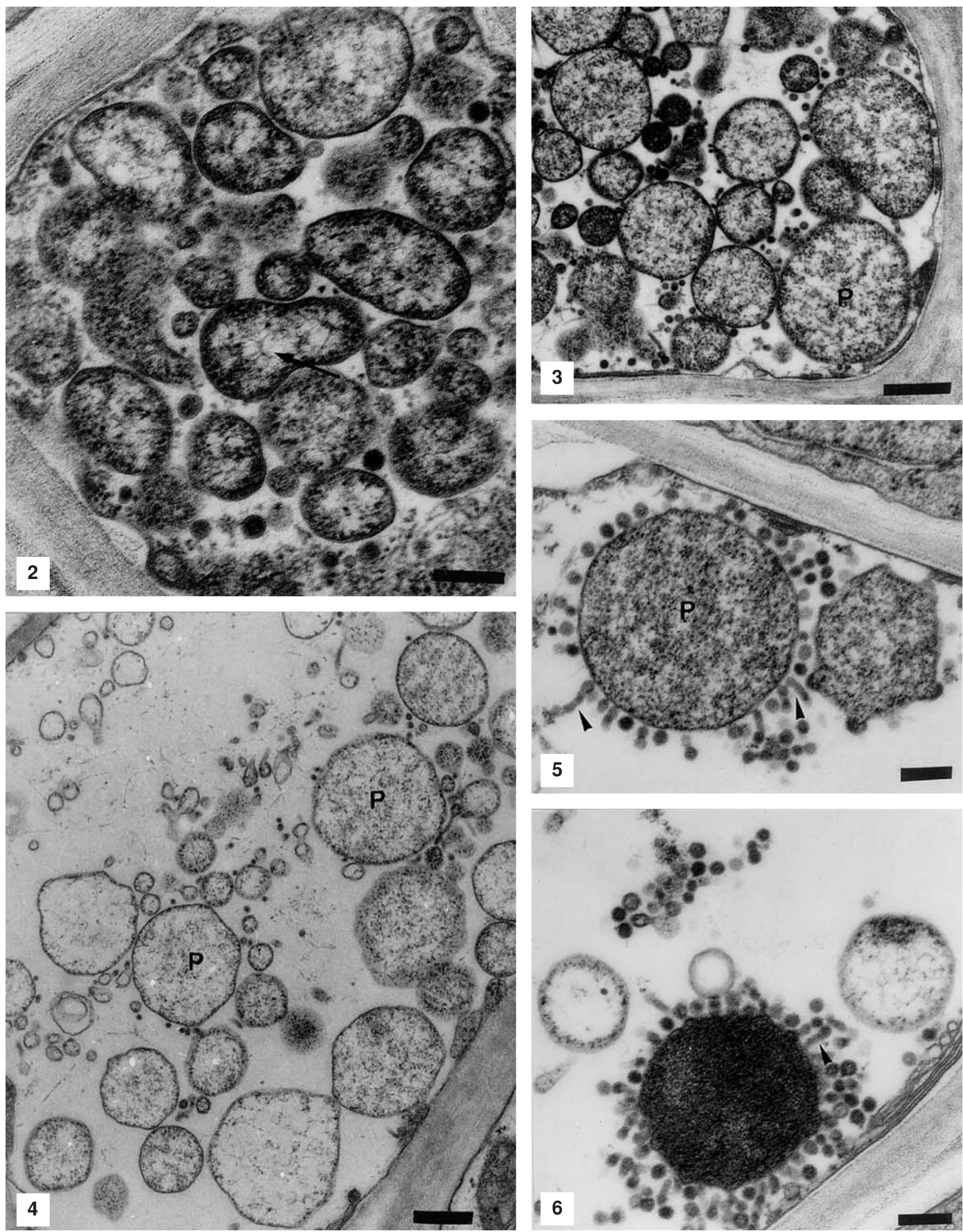

Phytoplasma forms present in the sieve tubes of Gladiolus roots.

Fig. 2. Phytoplasmas have oval shape and well distinguished middle part, in which nucleoid (arrow) is seen and on the border of the cell dark, granular part can be seen. $B a r=200 \mathrm{~nm}$.

Fig. 3. Round shaped phytoplasmas (P) in which the nucleoid can not be seen. Bar $=200 \mathrm{~nm}$

Fig. 4. Phytoplasmas (P), in which structure electrolucent protoplast is seen. $B a r=200 \mathrm{~nm}$.

Fig. 5, 6. Spherical shape structures $(\mathrm{P})$ with homogenous protoplast and finger shape protrusions (arrowheads) are seen. Bar $=200 \mathrm{~nm}$. 

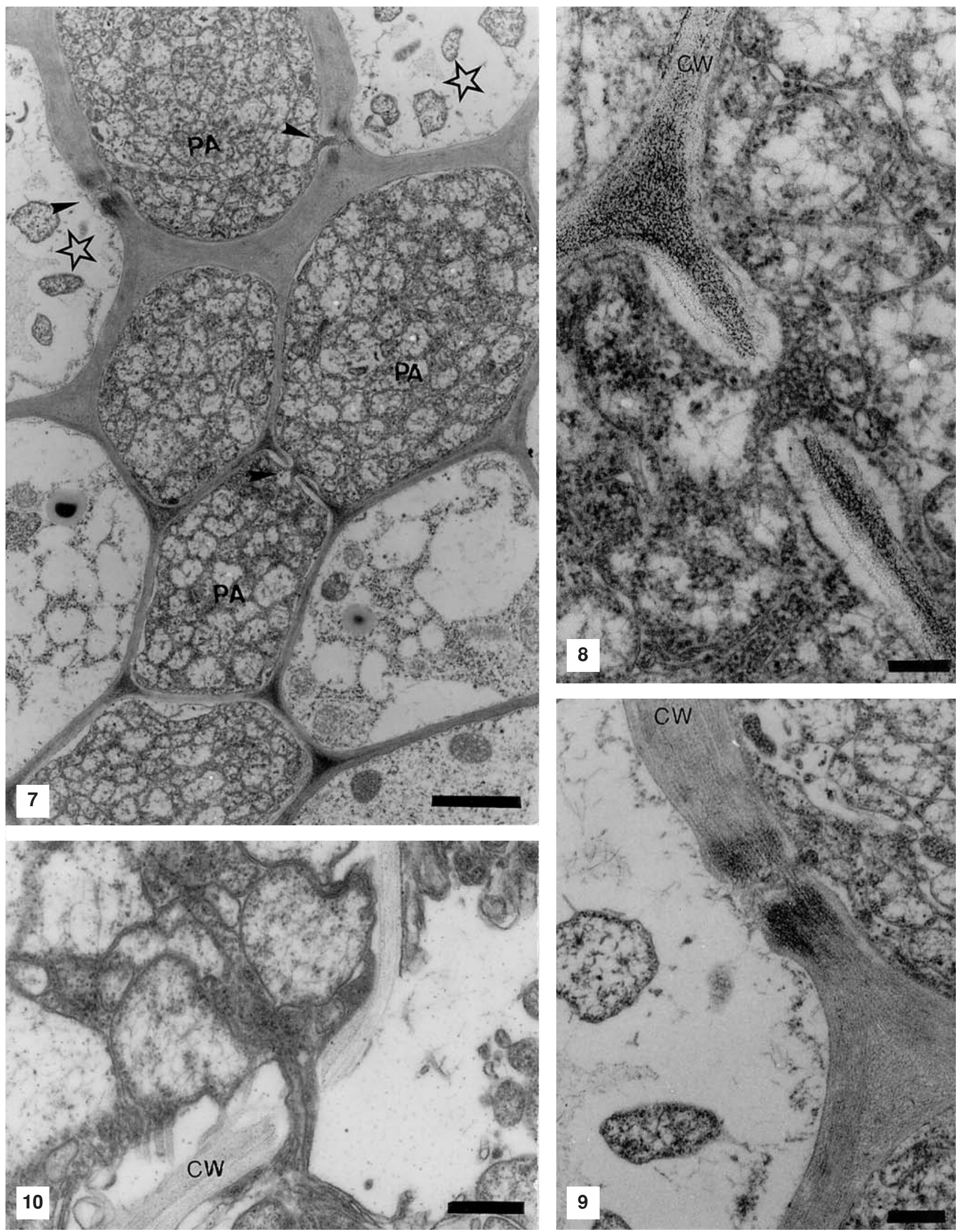

Fig. 7. Root phloem with sieve tubes (stars) with phytoplasmas and a few parenchyma cells (PA) tightly filled with phytoplasmas. Cell walls between parenchyma cells as well as between parenchyma cells and sieve tubes are not continous (arrowheads). Bar $=7 \mu \mathrm{m}$.

Figs 8 and 9. Damages in cell walls (CW) between two parenchyma cells. In cell walls around these damage dark granular deposits of tannins are apparent. Bar on Fig. $8=500 \mathrm{~nm}$, bar on Fig. $9=1 \mu \mathrm{m}$.

Fig. 10. Damage in cell walls (CW) between two parenchyma cells around which no tannin deposits in the cell walls appear. Bar $=500 \mathrm{~nm}$. 

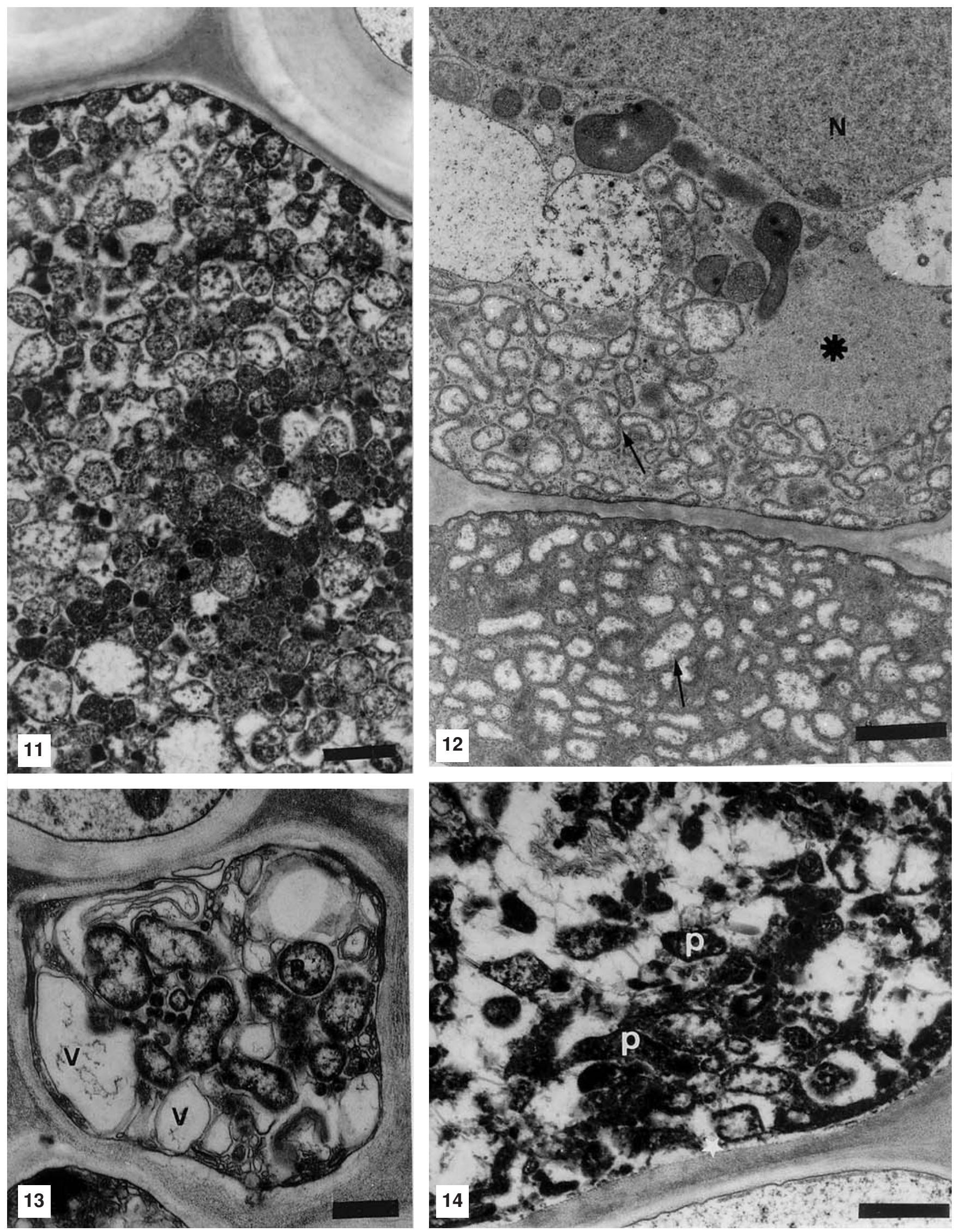

Fig. 11. Parenchyma cell filled with phytoplasmas. In the cell protoplast dark granules and vesicles being a sign of the cell degeneration are present. Bar $=10 \mu \mathrm{m}$. Fig. 12. Companion cell (above) and parenchyma cell (below) infected with phytoplasma. These cell protoplasts were modified and had regions filled with tightly packed phytoplasma cells. The homogenous region of cytoplasm (star) in companion cell is seen. The plastids and mitochondria of the cell situated near nucleus $(\mathrm{N})$, in the region of protoplast, where phytoplasma are not present. Healthy looking phytoplasmas are present in both cells (arrows). Bar $=1 \mu \mathrm{m}$. Fig. 13. The cell with reduced vacuoles $(\mathrm{V})$ and phytoplasmas $(\mathrm{P})$. Bar $=500 \mathrm{~nm}$.

Fig. 14. Parenchyma cell with degeneration symptoms, like discontinuity of the plasma membrane and with degenerating phytoplasmas $(\mathrm{P}) . \mathrm{Bar}=500 \mathrm{~nm}$. 

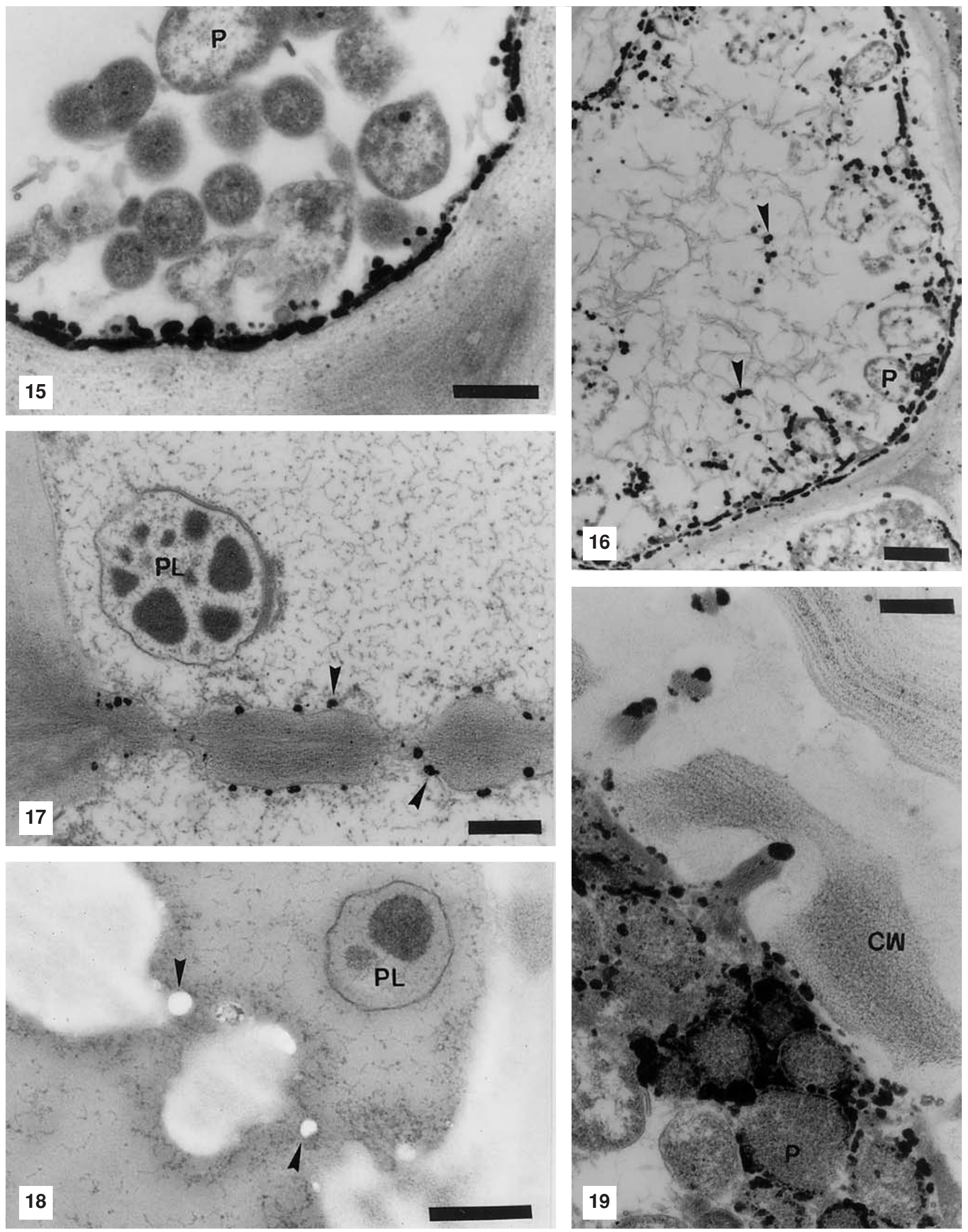

Fig. 15. Sieve tube of infected plant with phytoplasmas $(\mathrm{P})$ in the lumen. The numerous calcium antimonite deposits are present on the sieve tube plasma membrane. $B a r=250 \mathrm{~nm}$.

Fig. 16. Sieve tube of infected plant with phytoplasmas in the lumen. The numerous calcium antimonite deposits situated on sieve tube plasma membrane and in the protoplast (arrowhead). $B a r=500 \mathrm{~nm}$.

Fig. 17. The deposits situated around the sieve tube plate (arrowheads). No damages of sieve tube plastid (PL) nor calcium antimonite deposits in it can be observed. Bar $=500 \mathrm{~nm}$.

Fig. 18. The control sample treated with EGTA. Transparent regions situated near the wall of sieve tube plate (arrowheads) indicate the putative places were calcium antimonate deposits were present. $B a r=250 \mathrm{~nm}$.

Fig. 19. Sieve tube with phytoplasmas $(\mathrm{P})$ situated near the sieve tube plate $(\mathrm{CW})$. The deposits are present near the phytoplasmas in the protoplast. Bar $=250 \mathrm{~nm}$. 

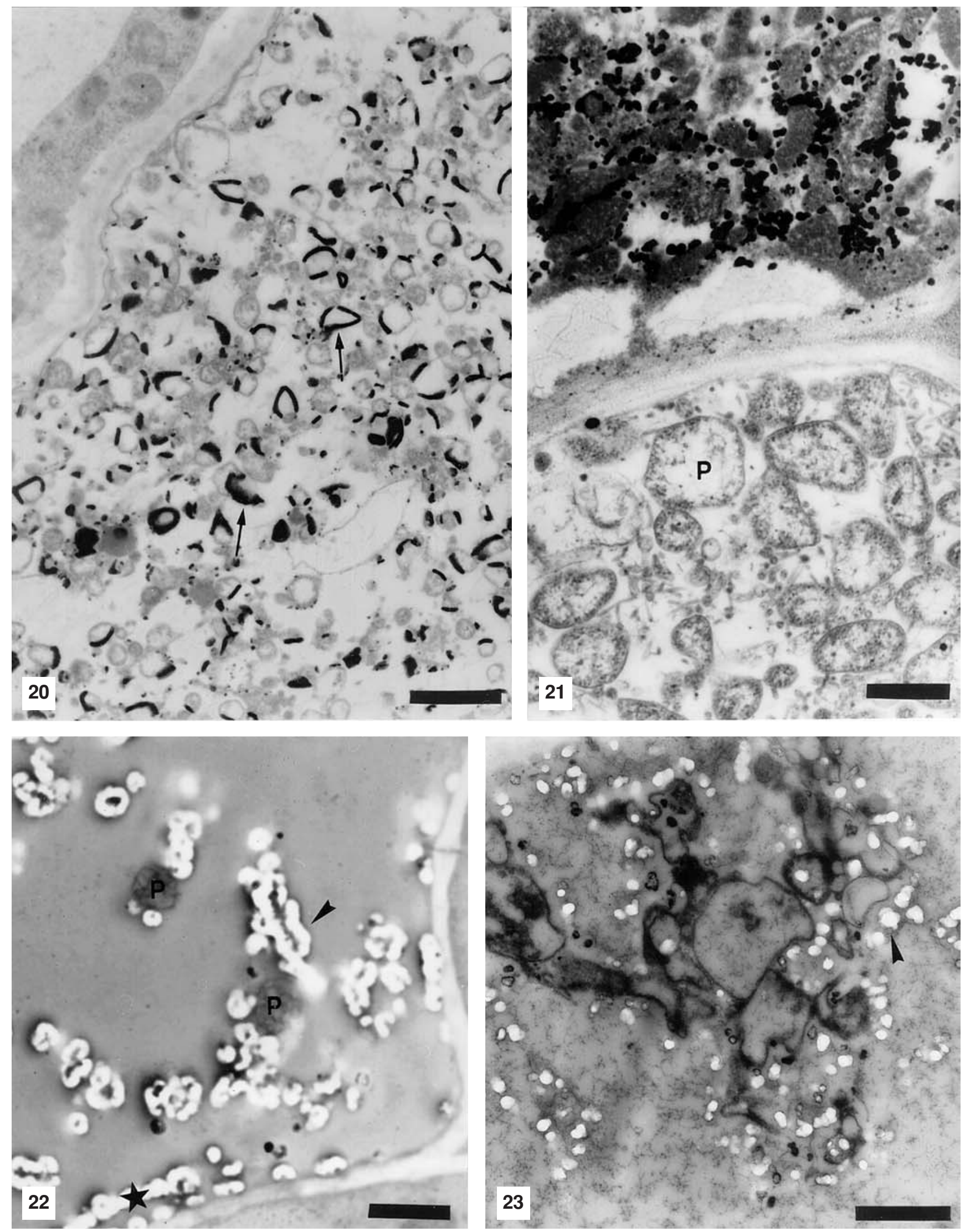

Fig. 20. Phloem parenchyma cell infected with phytoplasmas. Among numerous phytoplasmas deposits of calcium antimonite (arrows) are present. Bar $=1 \mu \mathrm{m}$. Fig. 21. Two phloem parenchyma cells. The upper cell shows degeneration changes in protoplast and numerous calcium antimonite deposits. Lower cell exhibiting few symptoms of degeneration although is filled with phytoplasmas. The cell showed limited number of calcium antimonite deposits. Bar $=500 \mathrm{~nm}$. Fig. 22. Phloem parenchyma cell infected with phytoplasmas. The sample treated with EGTA. Transparent regions in the cytoplasm (arrow heads) and along plasma membrane (star) indicate the putative places were calcium antimonate deposits were present. Two phytoplasmas (P) are present in the cell. Bar $=500 \mathrm{~nm}$.

Fig. 23. Phloem parenchyma cell infected with phytoplasmas. The sample treated with EGTA. Transparent regions (arrow heads) indicate the putative places were calcium antimonate deposits were present. Bar $=500 \mathrm{~nm}$. 

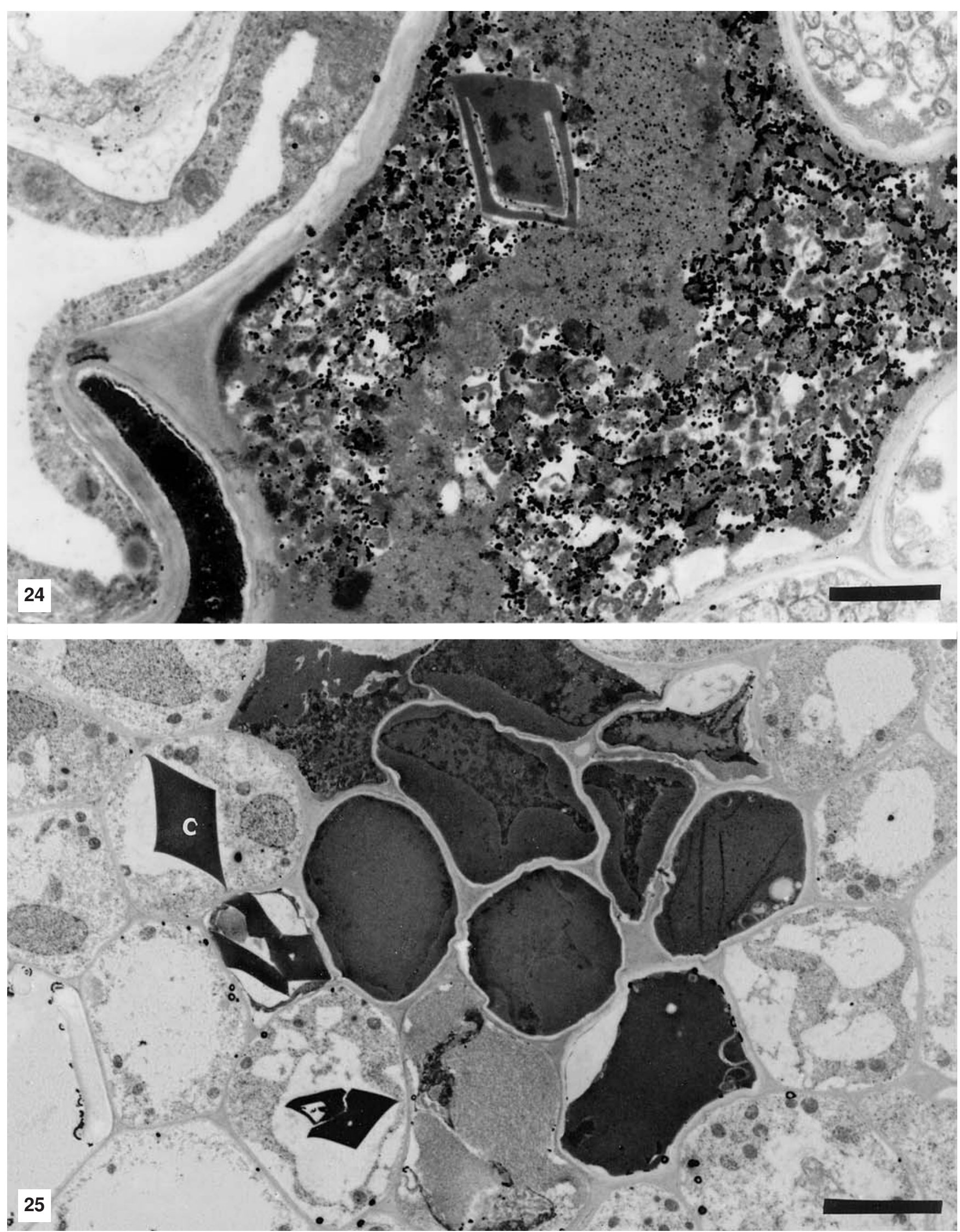

Fig. 24. Necrotising phloem parenchyma cell. Numerous deposits can be seen in the region of protoplast where phytoplasmas are present. Bar $=1 \mu \mathrm{m}$. Fig. 25. The group of necrotic phloem cells with dark, homogenous protoplast. Paracrystals (C) are present in vacuoles of some cells. Bar $=5 \mu \mathrm{m}$. 

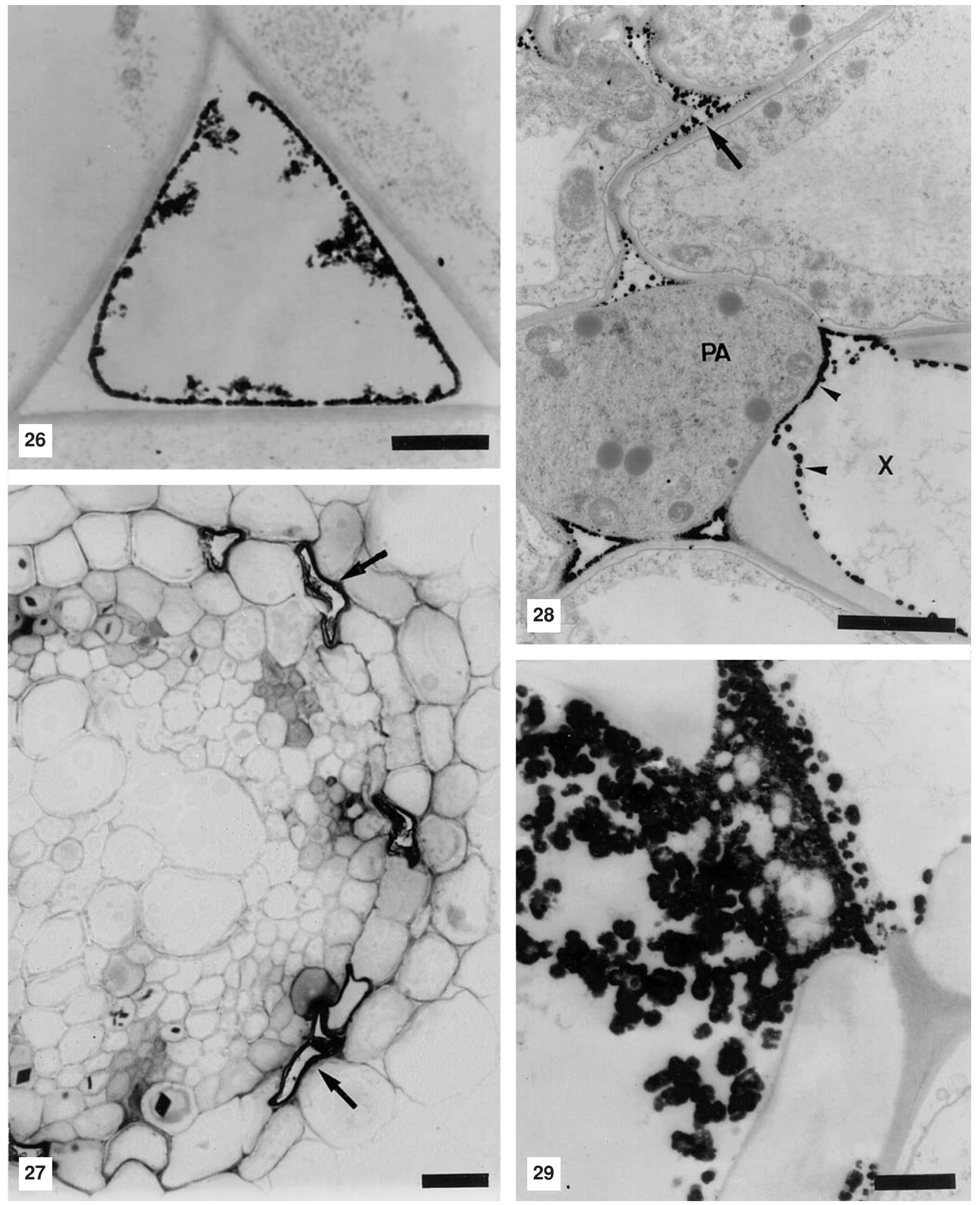

Fig. 26. Intercellular space between cortex parenchyma cells of infected plant root with calcium antimonite deposits. Bar $=2 \mu \mathrm{m}$.

Fig. 27. Semithin section of infected root stele with deposits in endodermis (arrows). The section is not stained and photographed under light microscopy. Bar $=20 \mu \mathrm{m}$.

Fig. 28. Root xylem parenchyma cells (PA) with deposits in intercellular spaces (arrows) and xylem element (X) with deposits (arrowhead) in the lumen. Bar $=2 \mu \mathrm{m}$.

Fig. 29. Calcium antimonite deposits (arrows) in xylem element (X). Bar = $500 \mathrm{~nm}$. 

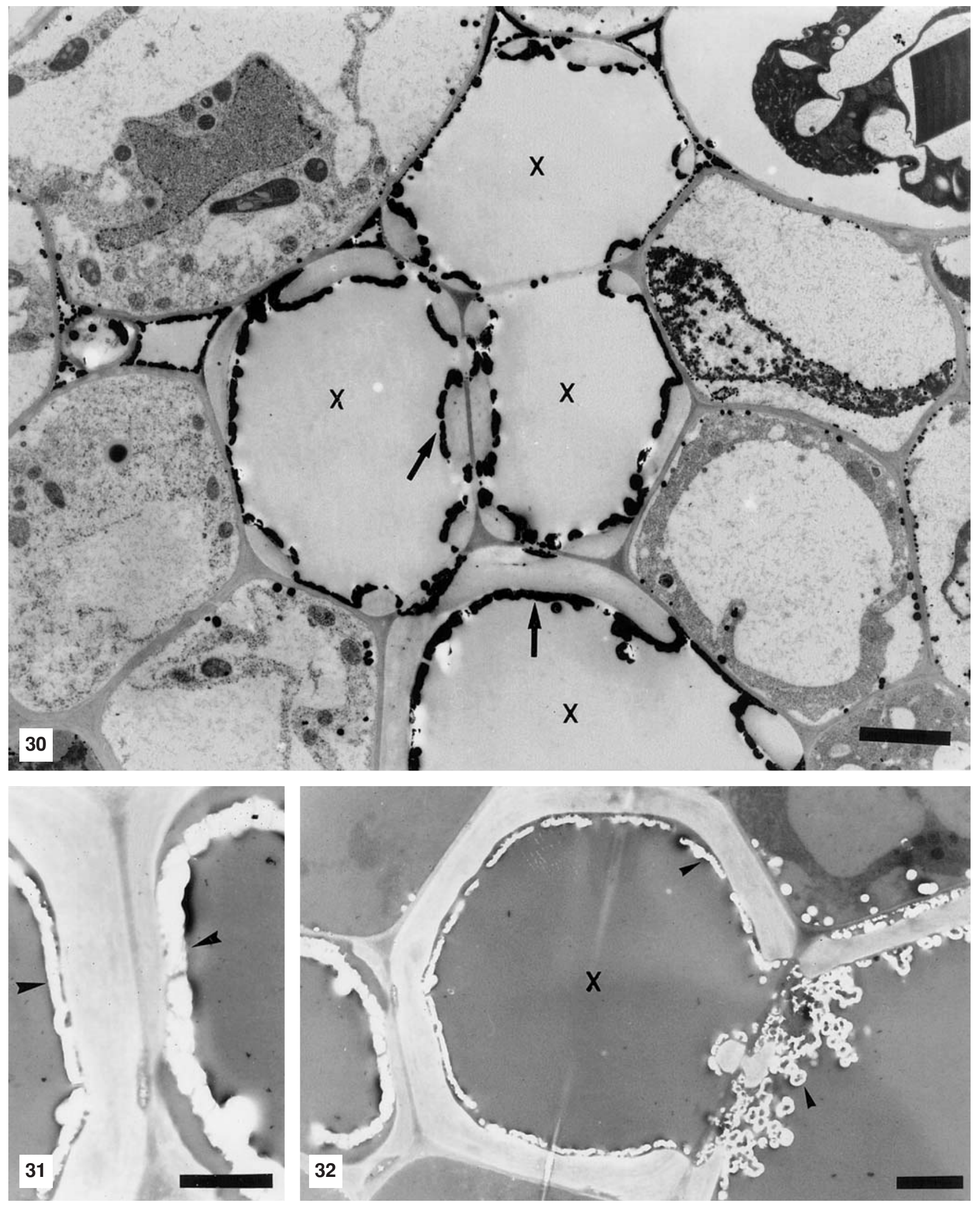

Fig. 30. Calcium antimonate deposits (arrows) present in tracheary elements form clusters around the thickened cell walls $(\mathrm{CW})$. Bar $=3 \mu \mathrm{m}$.

Figs 31,32 . The control treated with EGTA. Transparent regions in xylem element lumen, near the cell walls (arrow heads) indicate the putative places were calcium antimonate deposits were present. Bar $=500 \mathrm{~nm}$. 
small signs of degeneration, and seemed to be in good condition. Such a shape of phytoplasma cells was described previously (Kamińska et al. 1999). Closer investigation allowed us to find also phytoplasma cells of a different shape. There, in the sieve tubes oval shaped phytoplasmas with electronlucent protoplast were observed (Fig. 4). These phytoplasmas were regarded as a degenerating. Such phytoplasmas were not observed in parenchyma cells. Moreover, spherical shaped structures (Figs 5,6) with homogenous protoplast and finger-shaped protrusions were observed in sieve tubes They were also regarded as phytoplasma cells. In the degenerating parenchyma cells contracted phytoplasmas with dark, clumped protoplast were observed (Fig. 24).

\section{Calcium deposits in infected cells}

Uninfected and infected plant roots differed in the number of calcium deposits. In root cortex of infected plants numerous deposits were present in intercellular spaces (Fig. 26). Such deposits were not observed in uninfected plants roots. In sieve tubes of infected plants there were numerous calcium antimonite deposits (Figs 15, 16), situated on both sides of sieve tube plasma membrane. The deposits were also present around the sieve-tube plate and in the sieve-tube lumen (Figs 16-19). The deposits were never situated on the surface of the sieve-tube plastids (Fig. 17). No damages of plastids nor calcium antimonite deposits were observed in them. Some deposits were situated near the phytoplasmas (Figs 16, 19), but this localization was not correlated with the number of phytoplasmas present in the sieve tube.

No deposits were observed in companion cells, even those infected by phytoplasma. Phloem parenchyma cells varied in the intensity of calcium deposits (Figs 20-25). Parenchyma cells from root stele of control plants had only a small amount of calcium deposits in their vacuoles, while cells from infected plants had large deposits situated mostly in the cytoplasm (Figs 20 and 24). There was also a group of parenchyma cells tightly filed with phytoplasma, which had no calcium deposits (Fig. 21). Several degrees of reactions in free calcium ions presence can be distinguished in parenchyma cells: (1) Parenchyma cells with little signs of degeneration and with oval, healthy looking phytoplasmas. These cells showed a small number or no calcium antimonite deposits. Cells situated near xylem were generally much stronger marked by calcium deposits than these situated near the pericycle. The number of deposits was correlated with phytoplasma presence and the degree of degeneration of these cells. Most of deposits appeared in cytosol between phytoplasma cells (Fig. 20). Much less deposits were observed in the border of the cells. (2) Cells with some degeneration symptoms such as a presence of various vesicles and dark fussy deposits, but with healthy looking phytoplasmas. These cells had deposits in the cytoplasma (Fig. 20). (3) Cells exhibiting degeneration changes in protoplast, discontinuity of the tonoplast and plasma membrane, and with degenerating phytoplasmas. Numerous deposits were present in the cytoplasm as well as near the plasma membrane. Parenchyma cells from infected plants situated near the pericycle had usually fewer calcium deposits, although they showed degeneration and necrotisation changes (Figs 24, 25). The deposits in these cells were situated in the same places as phytoplasmas (Fig. 24). No deposits were observed around the damaged cell walls.
Xylem elements of phytoplasma infected roots were strongly marked by calcium deposits. The deposits were present in tracheary elements (Figs 28-32). They formed clusters around the thickenings of cell walls. Such deposits were not observed in control-plant-root xylem. Also xylem-parenchyma cells from phytoplasma-infected plants had some calcium deposits, although phytoplasma were not observed in them. These deposits were localised on the inner surface of the plasma membrane, and in cytoplasm. The intercellular spaces of xylem parenchyma cells, if there were any, were also containing the deposits (Fig. 28)

\section{DISCUSSION}

Phytoplasmas are known to be present in the sieve tubes of phloem, but it has been reported that they can also infect companion (Lombardo et al. 1970; Worley 1970) and parenchyma cells (Worley 1970; Hirumi and Maramorosch 1973; Esau et al. 1976; Siller et al. 1987; Rudzińska-Langwald and Kamińska 2001b). Nevertheless, the infection of cell types other than sieve tubes is less frequent. The lack of photosynthetic system, of which presence is connected with oxygen production, is usually regarded as a factor stimulating the infection of cells other than sieve tubes. The lack of photosynthetically active chloroplasts may be the reason why phytoplasmas were found in parenchyma cells of Cuscuta odorata (Siller et al. 1987). The presence of phytoplasmas in root phloem of Vicia faba plants observed by Lherminier et al. (1994) is also an example of such situation. The presence of phytoplasmas in parenchyma cells of Gladiolus roots is in line with these observations.

The sieve elements of phloem were the main cell type to necrotise in phloem infected by phytoplasmas (Parthasarathy 1774; Rudzińska-Langwald and Kamińska 2001a). In gladiolus roots the biggest changes connected with necrotisation take place in the outer part of phloem where no sieve tubes were present in control roots.

The phytoplasmas show very big pleomorphism in their structure as a rule, but the structure of phytoplasma cells and their variability are also connected with the conditions of phytoplasmas, the aging of them. Although they were present in sieve tubes as well as in parenchyma cells, the degenerating phytoplasmas were different in these two kinds of cells. Different forms of phytoplasma cells, similar to those observed in gladiolus roots, were also observed in other phytoplasma infections (Hirumi and Maramorosch 1973; Rudzińska-Langwald and Kamińska 2001a), but the spherical shape forms (Fig. 5) were rather unusual.

The changes in cytosolic $\mathrm{Ca}^{2+}$ in phytoplasma-infectedplant cells reflect different processes associated with the infection. The phytoplasma infection takes place mainly in the sieve tubes, phloem elements highly specialized for the long-distance assimilates' transport. Changes in free $\mathrm{Ca}^{2+}$ in sieve tube sap have been proposed to be important in the regulation of phloem transport (Adviushko et al. 1997; Brauer et al. 1998). Indeed, the translocation of carbohydrates is reduced in phytoplasma infected plants (Lepka et al. 1999). Volk and Franceschi (2000) showed the evidence for the existence of a calcium channel in the sieve tube plasma membrane. The proposed calcium channels become activated during pathogen attack or wounding. The high level of calcium antimonite deposits on plasma membrane of 
sieve tubes infected by phytoplasma seems to indicate similar processes in phytoplasma infection. The flux of calcium ions to the sieve tube stimulates early responds to injury in legume plants (Knoublach et al. 2001). It is not known whether this phenomenon is limited to the Fabaceae or other plant families have the similar mechanism. In the case of Gladiolus plants, the high level of free $\mathrm{Ca}^{2+}$, indicated by the presence of calcium antimonite deposits around the sieve tube plate, seems to have no influence on sieve tube plastids, neither on occlusions of sieve-tube-plate pores by different material. This suggests, that high level of free $\mathrm{Ca}^{2+}$ has no influence to plug the sieve tubes.

Research during the last two decades has clearly established that $\mathrm{Ca}^{2+}$ acts as an intracellular messenger in plant defense against various pathogens (Stab and Ebel 1987; Mithofer et al. 1999; Blume et al. 2000). Plant cells recognize a pathogenic signal or elicitor produced by the pathogen and the recognition results in the activation of signaling cascades within the plant cell, which results in the generation of a defense response. Surprisingly, the presence of phytoplasmas in different cells, such as companion cells and some parenchyma cells, had no influence on changes in calcium ions imbalance in infected cells. The calcium signaling belongs to the early reactions on pathogen infection (Blume et al. 2000). The phytoplasma infection of Gladiolus plants is well established (Kamińska et al. 1999). Moreover it is a systemic reaction, which causes a not very strong defense reaction. Thus, the appearance of $\mathrm{Ca}^{2+}$ in some parenchyma cells seems to be connected with degeneration and necrotisation processes occurring in them. It is significant, that different cell types react to phytoplasma infection in different ways.

The damages of infected cell walls observed in some cases were connected with phytoplasma transport from cell to cell (Rudzińska-Langwald and Kamińska 1999). Around some of these damages, granular deposits of tannins were present in the cell walls, but not calcium antimonate deposits appeared. It is surprising that such damages caused by phytoplasma had no influence on calcium ions level.

The presence of calcium deposits in intercellular spaces of cortical parenchyma cells and in xylem conducting elements of infected plant roots seems to be the sign of changes of the processes occurring in root apoplast. The balance between free calcium ions and absorbed ones is essential to calcium transport. In phytoplasma infected plants the reduction of water and minerals' transport was observed (Chowdappa et al. 1995). Calcium long-distance transport takes place in xylem conducting elements (Bell and Biddulph 1963) and calcium ions are absorbed by cell wall anions (Dematry et al. 1984; Ferguson and Bollard 1976). The presence of calcium antimonite deposits in xylem elements near the walls and in the intercellular spaces in infected roots cortex parenchyma, unlike in control plant, indicates changes in absorption ability of these walls. Aborted differentiation and also necrotisation of endodermis cells could also be connected with processes occurring in root apoplast, which can have an influence on uptake of water and minerals from soil by the roots. Thus phytoplasma infections have an influence on calcium transport in plants by changing the ability of absorption of these ions in xylem apoplast.

\section{LITERATURE CITED}

AHRENS U., SEEMULLER E. 1992. Detection of DNA of plant pathogenic mycoplasmalike organisms by a polimerase chain reaction that amplifies a sequence of the 16S rRNA gene. Phytopathology 82: 828-832.

AVDIUSHKO S.A., YE X.S., CROFT K.P., KUC J. 1997. Phosphorylation of proteins in cucumber exudates and evidence for protein kinase activity. J. Plant Physiol. 150: 552-559.

BELL C.W., BIDDULPH O. 1963. Translocation of calcium. Exchange versus mass flow. Plant Physiol. 38: 610-614.

BLUME B., NURNBERGER T., NASS N., SHEEL D. 2000. Receptor-mediated increase in cytoplasmic free calcium required for activation of pathogen defense in parsley. Plant Cell 12: $1425-1440$.

BRAUER M., ZONG W., JELITTO T., SCHOBERT C., SANDERS D., KOMOR E. 1998. Free calcium ion concentration in sieve-tube sap of Ricinus communis L. seedlings. Planta 206: 103-107.

CHOWDAPPA P., BALASIMHA D., RAJAGOPAL V., RAVINDRAN P.S. 1995. Stomatal responses in areca nut palms affected with yellow leaf disease. J. Plantation Crops. 23: 116-121.

CLARKSON D.T. 1984. Calcium transport between tissues and its distribution in the plant. Plant Cell Environ. 7: 449-456.

DEMATRY M., MORVAN C., THELLIER M. 1984. Calcium and wall. Plant Cell Environ. 7: 441-448.

ESAU K, MAGYAROSY A.C., BREAZEALE V. 1976. Studies of the mycoplasma-like organism (MLO) in spinach leaves affected by the AY disease. Protoplasma 90: 189-203.

FERGUSON I.B., BOLLARD E.G. 1976. The movement of calcium in woody steams Ann. Bot. 40: 1057-1065.

HIRUMI H., MARAMOROSCH K. 1973. Intracytoplasmic mycoplasma - like bodies in phloem parenchyma cells of aster yellows - infected Nicotiana rustica. Phytopath. Zeitschrift 77: 71-83.

JIAN L.C., LI J.H., LI P.H. 1997. Alternations in ultrastructure and subcellular localisation of $\mathrm{Ca}^{2+}$ in poplar apical bud cell during the induction of dormancy. J. Exp. Bot. 48: 1195-1207.

KAMIŃSKA M., RUDZIŃSKA-LANGWALD A., KORBIN M. 1999. Occurrence and identification of aster yellows related phytoplasma in Gladiolus in Poland. Acta Physiol. Plantarum 21: 419-425.

KNOUBLAUCH M., PETERS W.S., EHLERS K., VAN BEL A.J.E. 2001. Reversible calcium-regulated stopcocks in legume sieve tubes. Plant Cell 13: 1221-1230.

LEPKA P., STITT M., MOLL E., SEEMULLER E. 1999. Effect of phytoplasmal infection on concentration and translocation of carbohydrates and amino acids in periwinkle and tobacco. Physiological and Molecular Plant Pathology 55: 59-68.

LHERMINIER J., COURTOIS M., CAUDWELL A. 1994. Determination of the distribution and multiplication sites of Flavescence Doree mycoplasma - like organisms in the host plant Vicia faba by ELISA and immunocytochemistry. Phytopathological and Molecular Plant Pathology 45: 125-138.

LOMBARDO G., BASSI M., GEROLA F.M. 1970. Mycoplasma development and cell alternations in white clover affected by clover dwarf. Protoplasma 70: 61-71.

MAGIE R.O, FLOYD F., SMITH F., BRIERLEY P. 1952. Occurrence of western aster yellows virus infection in Gladiolus in Eastern United States. Plant Dis. Reptr. 36: 468-470.

Mithofer A., EBEL J., BHAGWAT A.A., BOLLER T., NEUHAUS-URL G. 1999. Transgenic aqueorin monitors cytosolic calcium transients in soybean cells challenged with $\beta$-glucan or chitin elicitors. Planta 207: 566-574.

PARTHASARATHY M.V. 1974. Mycoplasmalike organisms associated with lethal yellowing disease of palms. Phytopathology 64: 667-674.

REDDY A.S.N. 2001. Calcium: silver bullet in signalling. Plant Science 160: 381-404. 
RUDD J., FRANKLIN-TONG V.E. 1999. Calcium signalling in plants. Cell Molecular Life Science 55: 214-232.

RUDZIŃSKA-LANGWALD A., KAMIŃSKA M. 1999. Cytopathological evidence for transport of phytoplasma in infected plants. Acta Soc. Bot. Pol. 68: 261-266.

RUDZIŃSKA-LANGWALD A., KAMIŃSKA M. 2001. Ultrastructural changes in aster yellows phytoplasma affected Limonium sinuatum Mill. plants. I. Pathology of conducting tissues. Acta Soc. Bot. Pol. 70: 173-180.

RUDZIŃSKA-LANGWALD A., KAMIŃSKA M. 2001. Ultrastructural changes in aster yellows phytoplasma affected Limonium sinuatum Mill. plants II. Pathology of cortex parenchyma cells. Acta Soc. Bot. Pol. 70: 273-279.

SATO T. 1967. A modified method for lead staining of thin sections. J. Electron Microsc. 16: 133-146.

SEEMULLER E., MARCONE C., LAUER U., RAGOZZINO A., GOLSH M. 1998. Current status of molecular classification of phytoplasmas. J. Plant Pathol. 80: 3-26.
SILLER W., KUCHBANDNER B., MARWITZ R., PETZOLD H., SEEMULLER E. 1987. Occurrence of mycoplasma - like organisms in parenchyma cells of Cuscuta odorata (Ruiz et Pav.). J. Phytopathology 119: 147-159.

SLOCUM R. D., ROUX S.J. 1982. An improved method for the subcellular localization of calcium using a modification of the antimonite precipitation technique. J. Histochem. Cytochem. 30: 617-629.

STAB M.R., EBEL J. 1987. Effects of $\mathrm{Ca}^{2+}$ on phytoalexin induction by fungal elicitor in soybean cells. Archives Bioch. Pioph. 257: 416-423.

VOLK G.M., FRANCESCHI V.R. 2000. Localization of a calcium channel-like protein in the sieve element plasma membrane. Aust. J. plant Physiol. 27: 779-786.

WORLEY J.F. 1970. Possible replicative forms of a mycoplasma - like organism and their location in aster yellows diseased $\mathrm{Ni}$ cotiana and an aster. Phytopathology 60: 284-292.

\title{
ZMIANY ULTRASTRUKTURALNE \\ ZACHODZĄCE W KORZENIACH GLADIOLUS X HYBRIDUS VAN HOUTTE PORAŻONYCH FITOPLAZMAMI Z GRUPY ASTER YELLOWS
}

\section{STRESZCZENIE}

\begin{abstract}
Przeprowadzono analizę struktury korzeni roślin Gladiolus $x$ hybridus porażonych fitoplazmami z grupy AY. W porównaniu do roślin kontrolnych system korzeniowy roślin porażonych był znacznie słabszy, korzenie były cieńsze, a budowa walca osiowego tych korzeni ulegała dezorganizacji. W korzeniach roślin porażonych obserwowano fitoplazmy występujące w rurkach sitowych, komórkach towarzyszących i komórkach miękiszu łykowego. W korzeniach przeprowadzono lokalizację wolnych jonów $\mathrm{Ca}^{2+}$ metodą Slocum and Roux (1982). Komórki walca osiowego korzeni roślin porażonych charakteryzowały się zwiększoną ilością depozytów wapniowych w protoplastach tych komórek, które były zainfekowane fitoplazmami. Stwierdzono występowanie zwiększonej ilości depozytów w rurkach sitowych. Depozyty te występowały na plazmolemmie, przy płytkach sitowych oraz w świetle elementu sitowego. Zwiększeniu ilości wolnych jonów wapniowych w rurkach sitowych nie towarzyszyły zmiany prowadzące do zatykania porów płytek sitowych. Porażone fitoplazmami komórki towarzyszące charakteryzowały się małą ilością depozytów antymonianu wapnia. Natomiast komórki miękiszowe charakteryzowały się zmiennym poziomem depozytów wapniowych, począwszy od komórek, w których występowały fitoplazmy a nie było depozytów, do komórek wykazujących duże depozyty wapniowe. Te ostatnie komórki wykazywały zmiany degeneracyjne. W korzeniach roślin porażonych obserwowano występowanie depozytów wapniowych w świetle naczyń drewna oraz w przestworach międzykomórkowych. Podobnych depozytów nie obserwowano w korzeniach roślin zdrowych.
\end{abstract}

SŁOWA KLUCZOWE: struktura łyka, depozyty wapniowe, fitoplazma, aster yellows. 